Saudi Journal of Business and Management Studies Abbreviated Key Title: Saudi J Bus Manag Stud ISSN 2415-6663 (Print) |ISSN 2415-6671 (Online) Scholars Middle East Publishers, Dubai, United Arab Emirates Journal homepage: https://saudijournals.com/sjbms

Original Research Article

\title{
Determinant of Stock Returns with Inflation as a Moderating Variable
} Rizky Zakariyya Rasyad, Rusdiah Iskandar, Musdalifah Azis**

Mulawarman University Magister Management, Faculty of Economy and Business, Mulawarman University, Samarinda, Indonesia

DOI: $10.36348 /$ sjbms.2020.v05i06.006

| Received: 25.05.2020 | Accepted: 06.06.2020 | Published: 26.06.2020

*Corresponding author: Musdalifah Azis

\section{Abstract}

One of the considerations of investors before investing their capital is to look at the company's financial performance. The variables used to view financial performance in this study are profitability, liquidity, and leverage, and macroeconomic variables, namely inflation as a moderating variable. The object of research is the consumer goods industry sector companies listed on the Indonesia Stock Exchange (IDX) for 6 years (2013-2018). Data needs to be analyzed obtained from the company's financial statements published through IDX and ICMD (Indonesia Capital Market Directory). The analytical tool used is multiple linear regressions and MRA (Moderate Regression Analysis).Based on the results of the analysis it is known that there is a determinant of stock returns which is further strengthened by inflation with a coefficient of determination from $18.3 \%$ to $24.3 \%$. The results showed that return on equity as a positive and significant determinant of stock returns, current ratio as a negative and significant determinant of stock returns, debt to assets ratio as a positive and significant determinant of stock returns, debt to equity ratio as a negative and significant determinant of stock returns stock returns, price earnings ratio as a positive and significant determinant of stock returns. While the moderating variable which is proxied by inflation is only able to moderate (strengthen) the debt to assets ratio as a determinant of stock returns and the debt to equity ratio as a determinant of stock returns. The results of this study are expected to make an empirical contribution to the determinants of stock returns by considering the impact of inflation that occurs and become a basis of reference for investors before investing their capital.

Keywords: Retun on equity, Current ratio, Debt to assets ratio, Debt to equity ratio, Price Earnings Ratio, Inflation, Stock returns.

Copyright @ 2020: This is an open-access article distributed under the terms of the Creative Commons Attribution license which permits unrestricted use, distribution, and reproduction in any medium for non-commercial use (NonCommercial, or CC-BY-NC) provided the original author and source are credited.

\section{INTRODUCTION}

The capital market provides facilities that unite two interests, namely investors who invest funds and those who need funds such as companies (issuers) [1]. The stock market is very important for sustainable economic growth because it can guarantee the flow of resources to productive investment opportunities [2]. Micro and macro-economic conditions make investors act and decide on something that will be applied to get a return [3]. Stock return is the level of profit enjoyed by investors for a stock investment it does [4]. Broadly speaking, the company's goal is maximum profit that can prosper the company or shareholder [5]. Net income can show returns for shareholders and a measure of management performance [6]. But stock price uncertainty is one of the obstacles [5]. Companies that are incorporated into the consumer goods industry have a high level of competition, thus demanding excellent company performance. The following table is a growth in the share prices of the consumer goods industry sector: 
Table-1: The growth of the consumer goods industry sector in 2017-2018

\begin{tabular}{|c|c|c|c|}
\hline No. & Sub Sector & $\mathbf{2 0 1 7}$ & $\mathbf{2 0 1 8}$ \\
\hline 1 & Food and Beverages Industry & $9,23 \%$ & $7,91 \%$ \\
\hline 2 & Pharmaceutical Industry & $4,53 \%$ & $-1,42 \%$ \\
\hline 3 & Cigarette Industry & $-0,64 \%$ & $3,52 \%$ \\
\hline 4 & Cosmetics Industry and Household Use & $4,43 \%$ & $4,56 \%$ \\
\hline 5 & Household Appliances Industry & $4,94 \%$ & $5,05 \%$ \\
\hline
\end{tabular}

Source: Data processed (2020).

The food and beverage industry contributes $35.5 \%$ of the total non-oil and gas industry GDP value. The low growth of the food and beverage industry in 2018 is due to the decline in world palm oil prices which has an impact on the decline in the value of palm oil exports and the overall export value of the food and beverage industry. The increase in cigarette industry exports in 2018 is one of the causes of the increase in industrial production of the consumer goods sector. In addition, public purchasing power in 2018 could be the cause of the increase in consumption goods growth [7].

But behind the growth of the consumer goods industry sector, it is out of sync when viewed from the average stock returns of the consumer goods industry sector. Stock returns experience fluctuations which can be seen in Figure 1. Below:

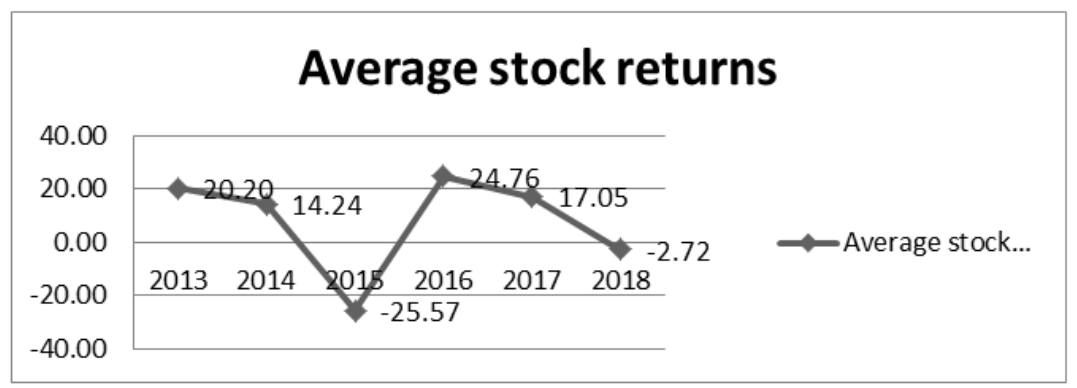

Fig-1: Average stock returns of the consumer goods sector in the 2013-2018 periods Source: Data processed (2020).

From this, then before buying shares, investors need to analyze company performance based on supporting and accurate data. Investors develop profitable investment strategies if they include macroeconomic variables in their decision making [8]. Therefore, by adding macroeconomic variables in analyzing the predictability of stock returns the data lead to more accurate results. In addition [9] stipulates that so far, there is no research on which single variable or combination best explains stock returns. With this gap, researchers enter the macroeconomic moderator variable, inflation, as a moderating variable. Because macroeconomic factors that are often used and received attention by capital market enthusiasts, namely inflation.

Inflation is a key macroeconomic that has a great impact on stock prices [10]. Inflation will increase the amount of purchasing power, the amount of goods and services, and a currency that will cause an increase in prices [11]. The increase in inflation has an impact on this decline in purchasing power which spreads to the stock market which causes price fluctuations [12]. Inflation has a relationship to affect stock returns directly [13]. So it is not wrong if inflation as a macro variable that affects the stock market and affects all returns on the stock market [14].
Financial ratios are a good measurement tool to find out the company's performance which is one of the internal factors of stock returns. Financial statements are often used as a comparison and benchmark of how competitive the company's performance is [4]. According to [15] the main purpose of analyzing financial statements is to build investments that will provide a consistent rate of return. Companies that have good financial performance will have an impact on increasing share prices on the capital market and affect investment returns [16].

\section{LITERATURE REVIEW Signalling Theory}

Information is an important element for investors because the information essentially presents information, notes or pictures both for past, current and future conditions for the survival of the company [17]. With the theory of the signal, causing a variety of reactions. One of the things that need to be seen to assess a company is the level of profitability, liquidity, leverage, and market value.

\section{Stock Returns}

In deciding to buy shares, the key factor that determines investors is the stock price [18]. Stock return is the level of profit or yield on a stock investment in a certain period [19]. Every investment, both short and 
long term, has the main goal to get a profit called return [1]. Stock returns can be calculated as follows:

Where:

$$
\mathrm{SR}=\mathrm{P}_{\mathrm{t}}-\mathrm{P}_{\mathrm{t}-1} / \mathrm{P}_{\mathrm{t}-1}
$$

SR : Stock returns

$\mathrm{P}_{\mathrm{t}} \quad$ : Current share price

$\mathrm{P}_{\mathrm{t}-1} \quad$ : Share price of the previous period

\section{Inflation}

Inflation affects the economy through income, wealth, and changes in the level and efficiency of production. Inflation will hurt investors who don't dare to risk it $[20,21]$. Has the idea that inflation is a crucial factor affecting stock returns. An increase in prices due to inflation is an increase in overall average prices and not an increase in certain products [19]. The inflation indicator according to www.bi.go.id are the Consumer Price Index (CPI) and the Wholesale Trade Price Index (WTPI). In this study the research data used is the Consumer Price Index (CPI).

\section{Return on Equity}

Return on Equity (ROE) compares the amount of net income with equity [22]. According to (Reilly \& Brown, 2012) ROE can be formulated as follows:

$$
\text { ROE }=\text { Net Income / Common Equity }
$$

\section{Current Ratio}

Current Ratio (CR) examines the relationship between current assets and current liabilities [15]. A high CR means the company's high ability to cover current liabilities of current assets. However, CR that is too high indicates a problem that is not good because the amount of inventory is relatively high from the level of sales so that the inventory turnover is low [3]. According to [15] CR can be formulated as follows:

$$
\mathrm{CR}=\text { Current Assets/Current Liabilities }
$$

\section{Debt to Assets Ratio}

Debt to Assets Ratio (DAR) is calculated by dividing the total debt of the company both short and long term by total assets [23]. According [22] DAR can be formulated as follows:

$$
\text { DAR }=\text { Total Liability/Total Assets }
$$

\section{Debt to Equity Ratio}

Debt to Equity Ratio (DER) is calculated by dividing the company's total debt (including current liabilities) by the shareholders' equity [23]. According to [15] DER can be formulated as follows:

$$
\text { DER }=\text { Total Long-Term Debt/Total Equity }
$$

\section{Price Earnings Ratio}

Price Earnings Ratio (PER) is the ratio between price per share and earnings per share [24]. According to [24], PER can be formulated as follows:

$$
\text { PER }=\text { Market Price of Stock/Earning Per Share }
$$

\section{ROE as a determinant of stock returns}

Investments are expected to receive returns in the future, although returns cannot be predicted precisely because there will always be risks associated with investment [5]. According to [22] ROE describes the level of revenue strength obtained by shareholders on their investment. So it can be concluded that ROE has a significant positive effect on stock returns. This is in line with research conducted by [25] and [26].

\section{Hypothesis I: ROE as a significant positive determinant of stock returns CR as a determinant of stock returns}

Investors usually monitor the current ratio (CR) to identify various companies that go out of bounds [22]. Low CR is usually considered to indicate a problem in liquidation, but if the $\mathrm{CR}$ is too high it is also not good because it shows the existence of unmanaged funds that can ultimately reduce the company's profitability [27]. So it can be concluded that CR has a significant negative effect on stock returns. This is in line with research conducted by [5].

\section{Hypothesis II: CR as a significant negative determinant of stock returns \\ $D A R$ as a determinant of stock returns}

Debt to Assets Ratio (DAR) is a measure used in analyzing financial statements to show the amount of collateral available to investors. The higher the DAR, the greater the risk faced by investors, because the company has low capital to finance assets [22]. This will be responded negatively by investors in the capital market. So the conclusion is drawn that the DAR has a significant negative effect on stock returns. This is in line with research conducted by [26].

\section{Hypothesis III: DAR as a significant negative determinant of stock returns DER as a determinant of stock returns \\ Debt to Equity Ratio (DER) that is too high has a bad impact on company performance, because a high level of debt means the company's interest expense will be greater and reduce profits [28]. So the higher the DER tends to reduce stock returns. So the conclusion is drawn that the DER has a significant negative effect on stock returns. This is in line with research conducted by [28, 29], and [1].}

\footnotetext{
Hypothesis IV: DER as a significant negative determinant of stock returns $P E R$ as a determinant of stock returns

Price Earnings Ratio (PER) indicates how investors assess the company's growth prospects in the future which is reflected in the price of shares that investors are willing to pay for each profit [24]. For investors, the higher the PER, the expected profit growth will also increase. So it is concluded that PER has a significant positive effect on stock returns. This is in line with research conducted by [30] and [1].
} 
Hypothesis V: PER as a significant positive determinant of stock returns

Inflation moderates ROE as a determinant of stock returns

High Return on Equity (ROE) often reflects the company's acceptance of good investment opportunities and effective cost management [22]. According to [31] inflation can increase company income and costs, if the increase in production costs due to inflation is higher than the increase in prices that can be enjoyed by the company then the company's profitability will go down and vice versa. So the conclusion is drawn that inflation can moderate the ROE relationship to stock returns.

Hyphotesis VI: inflation can moderate ROE as a determinant of stock returns

Inflation moderates $\mathrm{CR}$ as a determinant of stock returns

A good and stable Current Ratio (CR) indicates that its short-term obligations are fulfilled so that its operational activities are not disrupted in the process of generating profits. But when inflation occurs, the value of the currency weakens, a decline in income, results in the loss of optimism in the future for society and companies [32]. So it can be concluded that inflation can moderate the relationship of CR to stock returns.

\section{Hypothesis VII: inflation can moderate ROE as a determinant of stock returns \\ Inflation moderates DAR as a determinant of stock returns}

Investors prefer low Debt to Assets Ratio (DAR) because the level of security of funds is getting better [24]. The relationship between DAR and stock return can be moderated with inflation. Because the debt owned by the company will have an interest expense, and inflation can affect interest expenses. So that the conclusion drawn that inflation can moderate the DAR relationship to stock returns.

Hypothesis VIII: inflation can moderate ROE as a determinant of stock returns

Inflation moderates DER as a determinant of stock returns

Companies struggle to maximize the value of their companies by making optimal decisions [25]. The greater the DER shows the greater the cost of debt to be paid by the company so that profitability is reduced. If the company seeks funding from banks, it will greatly affect the economic turmoil, especially inflation. Because interest rates are based on reference to economic movements. So the conclusion is drawn that inflation can moderate the DER relationship to stock returns.

Hypothesis IX: inflation can moderate ROE as a determinant of stock returns

Inflation moderates PER as a determinant of stock returns

Price Earnings Ratio (PER) and stock prices have a direct or strong relationship. This will make investors respond positively and for certain earnings per share, investors are willing to pay a high price [1]. One item to calculate the PER and stock return is the stock price. A company's stock price can fluctuate with the movement of inflation. So the conclusion is drawn that inflation can moderate the relationship of PER to stock returns.

\section{Hypothesis X: inflation can moderate ROE as a determinant of stock returns Conceptual Frameworks}

The theoretical framework in this study can be described as follows:

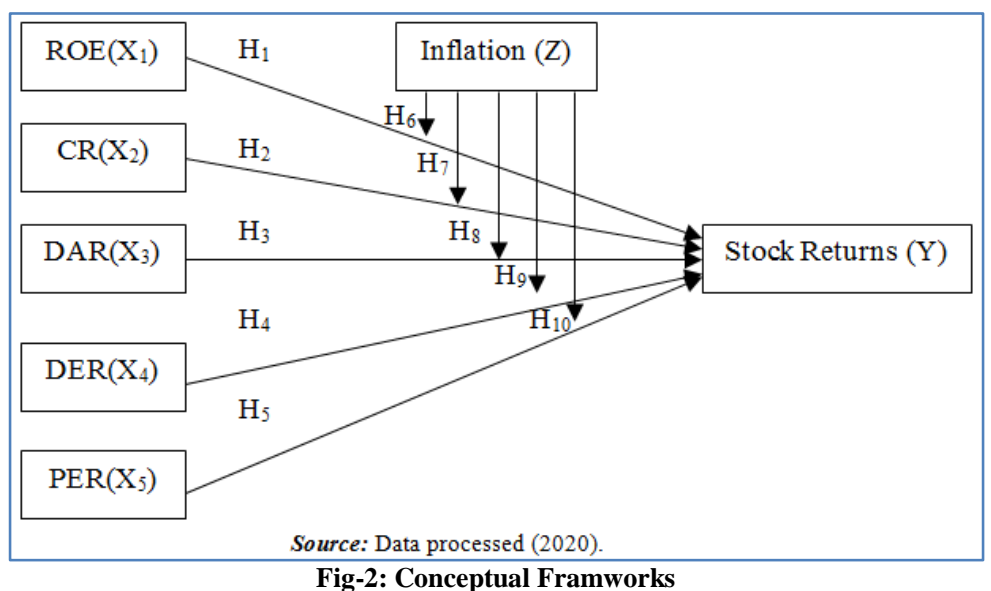

\section{METHODOLOGY}

\section{Sources and Type of Data}

The independent variables in this study are Return on Equity (X1), Current Ratio (X2), Debt to Assets Ratio (X3), Debt to Equity Ratio (X4), Price
Earnings Ratio (X5). Then the moderating variable is inflation $(\mathrm{Z})$ and the dependent variable is stock return (Y). The population in this study were industrial companies in the consumer goods sector which were listed on the Indonesia Stock Exchange in the period 2013-2018 totaling 52 companies. The sample is a 
portion of the number and characteristics possessed by the population to be studied [33]. The sampling method used in this study was purposive sampling [34]. Purposive sampling is done by taking samples from the population based on a certain criteria and obtained samples from this study a number of 25 samples with a period of observation of 6 (six) years.
The data used are secondary data obtained from the official website www.idx.co.id namely the annual report of each company.

\section{Measurement of Variables}

The summary measurements of each research variable are summarized in table 1. as follows:

Table-2: Research Variables

\begin{tabular}{|l|l|}
\hline Variables & Calculation method \\
\hline Return on Equity & Net Income/Common Equity \\
\hline Current Ratio & Current Assets/Current Liabilities \\
\hline Debt to Assets Ratio & Total Liability/Total Assets \\
\hline Debt to Equity Ratio & Total Long-Term Debt/Total Equity \\
\hline Price Earning Ratio & Market Price of Stock/ Earning Per Share \\
\hline Inflation & $\begin{array}{l}\text { Inflation recorded at Bank Indonesia published } \\
\text { monthly data which is calculated on average per year }\end{array}$ \\
\hline Stock Returns & Price of stock trice of stock $_{\mathrm{t}-1} /$ price of stock $_{\mathrm{t}-1}$ \\
\hline & Source data processed $(2020)$.
\end{tabular}

\section{Empirical Model Specification}

The data analysis method uses multiple linear regression models and moderating regression analysis with SPSS Version 23 analysis tool. The following is the regression equation used in this study:

Information:

$$
Y=\alpha+\sum_{i=1-5}^{N} \beta_{i} X_{i}+\sum_{i=1-5}^{N} \beta_{i} X_{i} Z_{i}+\varepsilon
$$

$\sum_{\mathrm{i}=1-5}^{\mathrm{N}} \beta_{\mathrm{i}} \mathrm{X}_{\mathrm{i}}=\beta_{1} X_{1}+\beta_{2} X_{2}+\beta_{3} X_{3}+\beta_{4} X_{4}+\beta_{5} X_{5}$

$\sum_{i=1-5}^{N} \beta_{i} X_{i} Z_{i}=\beta_{6} X_{1} Z_{1}+\beta_{7} X_{2} Z_{2}+\beta_{8} X_{3} Z_{3}+\beta_{9} X_{4} Z_{4}+\beta_{10} X_{5} Z_{5}$

Where:

$\begin{array}{ll}\mathrm{Y} & : \text { Stock returns } \\ \alpha & : \text { constant } \\ \mathrm{X}_{1} & : \text { Return on Equity (ROE) }\end{array}$

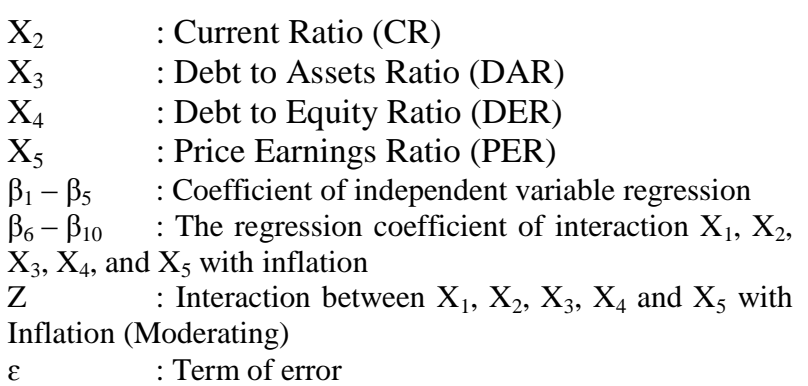

\section{RESULTS AND DISCUSSION} Coefficient of Determination

The coefficient of determination in multiple linear regressions is used to determine the percentage contribution of the influence of the independent variable on the dependent variable. The coefficient of determination can be seen in the following table 3 :

Table-3: Coefficient of Determinations

\begin{tabular}{|c|c|c|c|c|}
\hline Mod & R & R Square & Adjusted R Square & Std. Error of the Estimate \\
\hline 1 &, $428^{\mathrm{a}}$ &, 183 &, 154 & 36,58022 \\
\hline \multicolumn{5}{|c}{ Source: output SPSS V.23 (2020). }
\end{tabular}

The coefficient of determination in the moderation regression is used to determine the percentage contribution of the influence of the independent variable and moderation variable on the dependent variable. The coefficient of determination can be seen in the following table 4:

Table-4: Coefficient of Determinations (Moderation)

\begin{tabular}{|c|c|c|c|c|}
\hline Mod & R & R Square & Adjusted R Square & Std. Error of the Estimate \\
\hline 1 &, $493^{\mathrm{a}}$ &, 243 &, 183 & 35,95697 \\
\hline \multicolumn{4}{|c}{ Source: output SPSS V.23 (2020). } \\
\hline \multicolumn{4}{|c|}{}
\end{tabular}

Source: output SPSS V.23 (2020).

Based on the above table it can be said that the moderating variable can strengthen the influence of the independent variable on the dependent variable in this study as evidenced by the r-square results before the moderation variable is entered 0.183 or $18.3 \%$. After adding the variable r-square moderation increased to 0.243 or $24.3 \%$. 


\section{Regression Analysis}

To determine the effect of the independent variables on the dependent variable, regression analysis was performed. Testing is done with alpha of 0.05 $(5 \%)$. Following are the results of calculations based on SPSS 23 output:

Table-5: Regression analysis results

\begin{tabular}{|c|c|c|c|c|c|}
\hline \multirow{2}{*}{ Model } & \multicolumn{2}{|c|}{ Unstandardized Coefficients } & Standardized Coefficients & \multirow{2}{*}{ Sig. } \\
\cline { 2 - 5 } & B & Std. Error & Beta & & \\
\hline 1 (Constant) & $-4,484$ & 15,616 & &,- 287 &, 774 \\
\hline ROE &, 723 &, 219 &, 263 & 3,303 &, 001 \\
\hline CR &,- 062 &, 030 &,- 234 & $-2,084$ &, 039 \\
\hline DAR &, 622 &, 259 &, 316 & 2,402 &, 018 \\
\hline DER &,- 248 &, 088 &,- 356 & $-2,821$ &, 005 \\
\hline PER &, 041 &, 018 &, 177 & 2,327 &, 021 \\
\hline
\end{tabular}

Notes: $* \mathrm{a}<0.05$

Based on table 3. Above, the results can be interpreted as follows:

1. ROE variable has a significance level of 0.001 . This value is smaller than the alpha level of $5 \%(0.001<0.05)$ and a regression coefficient of 0.723 . That is, that the ROE variable partially has a positive and significant effect on stock returns.

2. The CR variable has a significance level of 0.039 . This value is smaller than the alpha level of $5 \%(0.039<0.05)$ and the regression coefficient is -0.062 . That is, that the CR variable partially has a negative and significant effect on stock returns.

3. The DAR variable has a significance level of 0.018 . This value is smaller than the alpha level of $5 \%(0.018<0.05)$ and a regression coefficient of 0.622 . That is, that the DAR variable partially has a positive and significant effect on stock returns.
4. The DER variable has a significance level of 0.005 . This value is smaller than the alpha level of $5 \%(0.005<0.05)$ and a regression coefficient of -0.248 . That is, that the DER variable partially has a negative and significant effect on stock returns.

5. The PER variable has a significance level of 0.021 . This value is smaller than the alpha level of $5 \%(0.021<0.05)$ and a regression coefficient of 0.041 . That is, that the PER variable partially has a positive and significant effect on stock returns.

To determine the effect of moderation variables on the dependent variable. Testing is done by comparing the significance value with alpha of 0.05 (5\%). Following are the results of calculations based on SPSS 23 output:

Table-4: Moderation regression analysis results

\begin{tabular}{|c|c|c|c|c|c|}
\hline \multirow{2}{*}{ Model } & \multicolumn{2}{|c|}{ Unstandardized Coefficients } & Standardized Coefficients & \multirow{2}{*}{ Sig. } \\
\cline { 2 - 6 } & B & Std. Error & Beta & & \\
\hline 1 (Constant) & $-21,723$ & 48,398 & &,- 449 &, 654 \\
\hline ROE*Inflation &, 030 &, 140 &, 069 &, 214 &, 831 \\
\hline CR*Inflation &,- 023 &, 019 &,- 459 & $-1,210$ &, 228 \\
\hline DAR*Inflation &, 314 &, 158 &, 973 & 1,993 &, 048 \\
\hline DER*Inflation &,- 153 &, 054 & $-1,295$ & $-2,843$ &, 005 \\
\hline PER*Inflation &, 003 &, 011 &, 067 &, 252 &, 801 \\
\hline
\end{tabular}

\section{Notes: $* \mathrm{a}<0.05$}

Based on table 4. Above, the MRA regression results can be interpreted as follows:

1. The level of significance of the interaction between ROE and inflation is 0.831 . This value is greater than the alpha level of $5 \%(0.831>0.05)$. So it can be concluded that inflation cannot moderate the effect of ROE on stock returns.

2. The level of significance of the interaction between $\mathrm{CR}$ and inflation is 0.228 . This value is greater than the alpha level of 5\% (0.228>0.05). So it can be concluded that inflation cannot moderate the effect of $\mathrm{CR}$ on stock returns.
3. The level of significance of the interaction between DAR and inflation is 0.048 . This value is smaller than the alpha level of $5 \%(0.048<0.05)$. So it can be concluded that inflation can moderate (strengthen) the effect of DAR on stock returns.

4. The level of significance of the interaction between DER and inflation is 0.005 . This value is smaller than the alpha level of $5 \%(0.005<0.05)$. So it can be concluded that inflation can moderate (strengthen) the effect of DER on stock returns.

5. The level of significance of the interaction between PER and inflation is 0.801 . This value is 
greater than the alpha level of $5 \%(0.801>0.05)$. So it can be concluded that inflation cannot moderate the effect of PER on stock returns.

\section{CONCLUSION}

This research is an empirical study that aims to find out the factors that influence stock returns with inflation as a moderating variable. Test results that have been done previously show the results that partially all independent variables (return on equity, current ratio, debt to assets ratio, debt to equity ratio, price earnings ratio) have a significant effect on the dependent variable (stock returns). The company's external factors such as inflation are only able to moderate (strengthen) the effect of the relationship of debt to assets ratio on stock returns and debt to equity ratio on stock returns. The results of this study are expected to be used as a basis for analysis for investors before investing so that investment decisions that will be taken are not wrong and have a good impact on investors. And for further researchers, it is better to add other variables based on financial statements and observation periods, and add moderation variables that have a stronger influence besides inflation.

\section{REFERENCES}

1. Basarda, R. F., Moeljadi, M., \& Indrawati, N. K. (2018). Macro and Micro Determinants of Stock Return Companies in LQ-45 Index. Jurnal Keuangan Dan Perbankan, 22(2), 310-320.

2. Uddin, M. R., Rahman, S. M. Z., \& Hossain, M. R. (2013). Determinants of Stock Prices in Financial Sector Companies in Bangladesh- A Study on Dhaka Stock Exchange ( DSE ). Interdisciplinary Journal of Contemporary Research in Business, 5(3), 471-480.

3. Dama, H., Mas'ud, M., Chalid, L., \& Sukmawati, S. (2018). The Influence of the Dividend Payout Ratio (DPR) and the Current Ratio ( CR ) Against the Growth of Share Prices in the Service Sector Companies the Period 2011 - 2015 , in Indonesia. International Journal of Innovate Science and Research Technology, 3(5), 481-489.

4. Goodarzi, A. (2017). Do Based-Market Data Predict Stock Return Better Than Accounting Data? The Case of Tehran Stock Exchange ( TSE ). International Business and Management, 14(2), 1-7.

5. Yuliarti, A., \& Diyani, L. A. (2018). The Effect of Firm Size, Financial Ratios and Cash Flow On Stock Return. The Indonesian Accounting Review, 8(2), 229-243.

6. Campbell, J. Y., \& Shiller, R. J. (1988). Stock Prices, Earnings, and Expected Dividends. Journal of Finance, 43(3), 661-676.

7. Kementrian Perindustrian RI, R. I. (2019). Analisis Perkembangan Industri Edisi I - 2019. Jakarta.

8. Singh, T., Mehta, S., \& Varsha, M. S. (2011). Macroeconomic Factors and Stock Returns: Evidence From Taiwan. Journal of Economics and
International Finance, 2(4), 217-227.

9. Idris, I., \& Bala, H. (2015). Firms' Specific Characteristics and Stock Market Returns (Evidence from Listed Food and Beverages Firms in Nigeria). Research Journal of Finance and Accounting, 6(16), 188-201.

10. Eldomiaty, T., Saeed, Y., Hammam, R., \& Aboulsoud, S. (2018). The Associations between Stock Prices, Inflation Rates, Interest Rates are Still Persistent. Journal of Economics, Finance and Administratice Science.

11. Sathyanarayana, S., \& Gargesa, S. (2018). An Analytical Study of the Effect of Inflation on Stock Market Returns. International Journal of Management and Social Sciences, 13(02), 48-64.

12. Sokpo, J. T., Iorember, P. T., \& Usar, T. (2017). Inflation and Stock Market Returns Volatility: Evidence From The Nigerian Stock Exchange. Munich Personal Repec Archive, 1-19.

13. Kurniasari, W., Wiratno, A., \& Yusuf, M. (2018). Pengaruh Inflasi Dan Suku Bunga Terhadap Return Saham Dengan Profitabilitas Sebagai Variabel Intervening Di Perbankan Yang Terdaftar Di Bursa Efek Indonesia Tahun 2013-2015. Journal of Accounting Science, 2(1), 67-90.

14. Hemamala, R. K. K., \& Jameel, A. M. L. (2016). Relationship Between Inflation and Stock Market Return: Special Reference to the Colombo Stock Exchange ( CSE ). International Research Conference, 40-48.

15. Reilly, F. K., \& Brown, K. C. (2012). Invesment Analysis and Portofolio Management (10th ed.). Mason: South Western Cengage Learning.

16. Al-Tamimi, H. A. H., \& Kalli, A. A. (2009). Financial literacy and investment decisions of UAE investors. Journal of Risk Finance, 10(5), 500-516.

17. Ross, S. A. (1977). The Determination of Financial Structure: The Incentive-Signalling Approach. The Bell Journal of Economics, 8(1), 23-40.

18. Gill, A., Biger, N., \& Mathur, N. (2012). Determinants of equity share prices evidence from American firms. International Research Journal of Finance and Economics, (90), 176-192.

19. Hussein, A. A. (2017). Effect of Inflation Rate on Stock Market Returns In Uganda Security Exchange. 1-29.

20. Samuelson, P. A., \& Nordhaus, W. D. (1994). Makro Ekonomi (14th ed.). Jakarta: Erlangga.

21. Tripathi, V., \& Kumar, A. (2014). Relationship between Inflation and Stock Returns - Evidence from BRICS markets using Panel Co integration Test. International Journal of Accounting and Financial Reporting, 4(2), 647-658.

22. Horne, J. C. Van, \& Wachowicz Jr, J. M. (2012). Prinsip-Prinsip Manajemen Keuangan (13th ed.; E. S. Suharsi, Ed.). Jakarta: Salemba Empat.

23. Brigham, E. F., \& Ehrhardt, M. C. (2014). Financial Management Theory and Practice (14th 
ed.; E. Joyner, Ed.). United States: South Western Cengage Learning.

24. Brigham, E. F., \& Houston, J. F. (2010). DasarDasar Manajemen Keuangan (11th ed.; Salemba Empat, Ed.).

25. Khan, W., Naz, A., Khan, M., Khan, W. K. Q., \& Ahmad, S. (2013). The Impact of Capital Structure and Financial Performance on Stock Returns "A Case of Pakistan Textile Industry." Middle East Journal of Scientific Research, 16(2), 289-295.

26. Ghi, T. N. (2015). The Impact of Capital Structure and Financial Performance on Stock Returns of The Firms in Hose. International Journal of Information Research and Review.

27. Sugiarti, Surachman., \& Aisjah, S. (2015). Pengaruh Kinerja Keuangan Terhadap Return Saham Studi Pada Perusahaan Manufaktur Yang Terdaftar di Bursa Efek Indonesia). Jurnal Aplikasi Manajemen (JAM), 13(2), 282-298.

28. Acheampong, P., Agalega, E., \& Shibu, A. K. (2014). The Effect of Financial Leverage and Market Size on Stock Returns on the Ghana Stock Exchange : Evidence From Selected Stocks in the Manufacturing Sector. International Journal of Financial Research, 5(1), 125-134.
29. Sayedy, B., \& Ghazali, M. Z. (2017). The Impact of Microeconomic Variables on Stock Return by Moderating of Money Supply. Asian Social Science, 13(12), 191-200.

30. Petcharabul, P., \& Romprasert, S. (2014). Technology Industry on Financial Ratios and Stock Returns. Journal of Business and Economics, 5(5), 739-746.

31. Tandelilin, E. (2014). Portofolio dan Investasi Teori dan Aplikasi (5th ed.). Yogyakarta: Kanisius.

32. Bozkurt, C. (2014). Money, Inflation and Growth Relationship: The Turkish Case. International Journal of Economics and Financial Issues, 4(2), 309-322.

33. Ikbal, M. (2012). Metodologi Penelitian untuk Ekonomi dan Bisnis (1st ed.). Yogyakarta: Interpena.

34. Sugiyono. (2016). Statistika Untuk Penelitian. Bandung: Alfabeta.

35. Sudana, I. M. (2015). Manajemen Keuangan Perusahaan (2nd ed.; N. I. Sallama, Ed.). Jakarta: Erlangga.

36. www.bi.go.id.

37. www.idx.co.id. 